\title{
Antitumor, Antibiotic and Antileishmanial Properties of the Pyranonaphthoquinone Psychorubrin from Mitracarpus frigidus
}

\author{
RODRIGO L. FABRI ${ }^{1}$, RICHARD M. GRAZUL ${ }^{2}$, LIDIANE O. DE CARVALHO ${ }^{3}$, ELAINE S. COIMBRA ${ }^{3}$, \\ GABRIELE M.M. CARDOSO ${ }^{4}$, ELAINE M. DE SOUZA-FAGUNDES ${ }^{4}$, ADILSON D. DA SILVA ${ }^{2}$ and ELITA SCIO ${ }^{1}$ \\ ${ }^{1}$ Laboratório de Produtos Naturais Bioativos, Departamento de Bioquímica, Instituto de Ciências Biológicas, \\ Universidade Federal de Juiz de Fora, Rua José Lourenço Kelmer, s/n, São Pedro, 36036-900 Juiz de Fora, MG, Brasil \\ ${ }^{2}$ Departamento de Química, Instituto de Ciências Exatas, Universidade Federal de Juiz de Fora, \\ Rua José Lourenço Kelmer, s/n, São Pedro, 36036-900 Juiz de Fora, MG, Brasil \\ ${ }^{3}$ Departamento de Parasitologia, Microbiologia e Imunologia, Instituto de Ciências Biológicas, \\ Universidade Federal de Juiz de Fora, Rua José Lourenço Kelmer, s/n, São Pedro, 36036-900 Juiz de Fora, MG, Brasil \\ ${ }^{4}$ Departamento de Fisiologia e Biofísica, Instituto de Ciências Biológicas, Universidade Federal de Minas Gerais, \\ Av. Antônio Carlos, 6627, Pampulha, 31270-901 Belo Horizonte, MG, Brasil
}

Manuscript received on September 13, 2011; accepted for publication on April 17, 2012

\begin{abstract}
The bioactivity guided fractionation of the dichloromethane extract of Mitracarpus frigidus afforded the pyranonaphthoquinone psychorubrin. This compound, hitherto unknown in the genus Mitracarpus, had its biological activity evaluated against one panel of bacteria and two fungi, three tumor cell lines (HL60, Jurkat and MCF-7) and four Leishmania species. Its identity was confirmed unambiguously by ${ }^{1} \mathrm{H},{ }^{13} \mathrm{C},{ }^{1} \mathrm{H}-\mathrm{COSY}$, IR and UV-Vis spectroscopy and mass spectrometry. Psychorubrin displayed a very promising antitumor with $\mathrm{IC}_{50}$ of 4.5, 5.6 and $1.1 \mu \mathrm{M}$ for HL60, Jurkat and MCF-7 cell lines, respectively. Antimicrobial activity, mainly against Cryptococcus neoformans (MIC of $87.3 \mu \mathrm{M}$ ) was observed. A pronounced antileishmanial potential was also verified with $\mathrm{IC}_{50}$ varying from 1.7 to $2.7 \mu \mathrm{M}$ for the Leishmania species tested. This is the first report of the presence of pyranonapthoquinones in the Mitracarpus genus, which may serve as a chemotaxonomical marker.
\end{abstract}

Key words: Mitracarpus frigidus, psychorubrin, pyranonaphthoquinone, Rubiaceae.

\section{INTRODUCTION}

The genus Mitracarpus, known in the vernacular as the girdlepods, consists of no fewer than 50 species (Arruda and Gomes 1996). However, there is very little information in the literature regarding the constituents of Mitracarpus spp. Mitracarpus scaber Zucc. ex Schult. \& Schult. F. is the most widely studied

Correspondence to: Elita Scio

E-mail: elita.scio@ufjf.edu.br species and is employed in traditional medicine in West Africa for headaches, toothache, amenorrhoea, dyspepsia, hepatic and veneral diseases, leprosy, and in the treatment of skin diseases (Bisignano et al. 2000). Previous studies have reported the isolation of gallic acid, 3,4,5-trimethoxybenzoic acid, 4-methoxyacetophenone, 3,4,5-trimethoxyacetophenone, kaempferol-3-O-rutinoside, rutin and psoralen (Bisignano et al. 2000) as well as ursolic 
and oleanolic acids from this species (Gbaguidi et al. 2005). With particular interest is the presence of the biologically active napthaquinone derivatives pentalongin (Moulis et al. 1992), its hydroquinone diglycoside, harounoside (Harouna et al. 1995), and benz $[\mathrm{g}]$ isoquinoline-5,10-dione (Okunade et al. 1999) in M. scaber. Several patents (Greff 1998, Spindler and Urbanec 2009, Tsuji and Nakanishi 2010) have been solicited using extracts of $M$. scaber as a skin lightening component and it may be the presence of these and other napthaquinones that are responsible for this action. Another species of Mitracarpus, M. villosus (Sw.) DC was studied and found to contain stigmasterol, 24-methylcholesta5-en-3 $\beta$-ol, and ursolic acid (Ekpendu et al. 2001).

Psychorubrin (1) (Figure 1) was first described in Psychotria rubra (Rubiaceae), a Chinese folk medicine which demonstrated activity against $\mathrm{KB}$ cells (Hayashi et al. 1987). Other authors erroneously attributed a different structure for psychorubrin to a napthoquinone isolated from $P$. camponutans which showed strong in vitro activity against brine shrimp, KB cells, and chloroquine-resistant $P$. falciparum (Jacobs et al. 2008). This compound was later shown to be psychorubrin by means of total synthesis. Three total syntheses of psychorubrin have also been reported (Kesteleyn et al. 1999, Bulbule et al. 2003, Nguyen and Kimpe 2004).

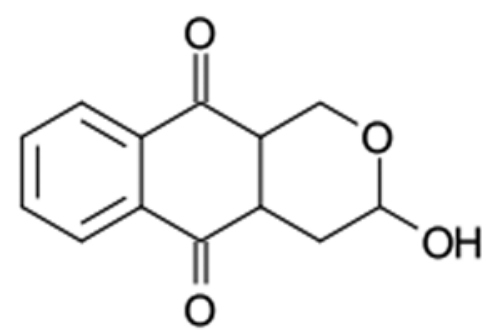

Figure 1 - The structure of psychorubrin (1) isolated from the aerial parts of Mitracarpus frigidus.

To the best of our knowledge, Mitracarpus frigidus (Willd. ex Roem. \& Schult.) K. Shum, an annual shrub commonly found in Brazil, has never been subjected to phytochemical investigation, except a recently published paper (Fabri et al. 2009). In that research article, we describe the antitumor, antimicrobial and antileishmanial properties of crude extracts of $M$. frigidus. Upon the discovery of strong biological activity of the dichloromethane $\left(\mathrm{CH}_{2} \mathrm{Cl}_{2}\right)$ extract, the authors sought to isolate the compound or compounds responsible for this activity.

\section{MATERIALS AND METHODS}

PLANT MATERIAL

Mitracarpus frigidus aerial parts were collected in Juiz de Fora, state of Minas Gerais, Brazil, in May, 2009. The plant was identified by Dra. Tatiana Konno from the Ecological and Socioenvironmental Core of Macaé/UFRJ. A voucher specimen (CESJ 46076) was deposited at the Leopoldo Krieger Herbarium at the Universidade Federal de Juiz de Fora.

EXTRACTION AND ISOLATION

Preparation of the crude $\mathrm{CH}_{2} \mathrm{Cl}_{2}$ extract was previously described in detail (Fabri et al. 2009). Purification of this extract was performed in the following manner: the $\mathrm{CH}_{2} \mathrm{Cl}_{2}$ extract (4.8 g) was chromatographed on a $74 \times 4 \mathrm{~cm}$ column of silica gel (70-230 mesh) with a gradient of increasing polarity $\left(\mathrm{CH}_{2} \mathrm{Cl}_{2}, \mathrm{CH}_{2} \mathrm{Cl}_{2}\right.$-EtOAc, EtOAc, EtOAc$\mathrm{MeOH}, \mathrm{MeOH}$ ) to obtain a total of twenty fractions. The fractions obtained were analyzed by thin layer chromatography on silica gel $60 \mathrm{~F}_{254}$ (Merck) using hexane: EtOAc, 60:40, v/v and hexane: EtOAc, $30: 70 \mathrm{v} / \mathrm{v}$ as the mobile phase for fractions $F_{1}$ to $F_{10}$ and fractions $F_{11}$ to $F_{20}$, respectively. Identification was made with a UV lamp (254 and $365 \mathrm{~nm}$ ) and with vanillin: sulfuric acid followed by heating. The fractions were pooled and concentrated on a rotary film evaporator under reduced pressure. While preparing the fractions for HPLC analysis (vide infra), we proceeded to dissolve the samples in methanol. Upon addition of methanol to fraction 
7, an off-white solid precipitated. This was filtered and dried under vacuum to yield $100 \mathrm{mg}(2.08 \%$ $\mathrm{w} / \mathrm{w}$ ) of the title compound (1). The sample was homogeneous by TLC with an Rf of 0.57 (hexane:EtOAc 7:3) and revealed as a brownishorange spot with vanillin-sulfuric acid.

\section{STRUCTURAL ELUCIDATION}

${ }^{1} \mathrm{H}-\mathrm{NMR}$ and COSY (300 MHz) and ${ }^{13} \mathrm{C}-\mathrm{NMR}$ (75 MHz) spectra were recorded on a Bruker DRX spectrometer using the residual solvent peak $\left(\mathrm{CHCl}_{3}\right)$ as reference. The IR spectrum was recorded as a $\mathrm{KBr}$ pellet on a Bomem B102 FT spectrophotometer. The UV spectrum was acquired in MeOH on a Shimadzu UV160 spectrophotometer. The EI mass spectrum was obtained on a HewlettPackard 5973 MSD spectrometer by direct insertion in the positive ion mode $(70 \mathrm{eV})$.

\section{HPLC ANALYSIS}

During the course of our investigations of the crude extract, it was necessary to develop an HPLC method suitable for determining the purity of the various column fractions which were obtained. These analyses were performed on an Agilent Technologies 1200 Series, with a PDA detector and automatic injector. The column employed was a Zorbax SB-18; $250 \times 4.6 \mathrm{~mm}, 5 \mu \mathrm{m}$ particle size. A linear gradient of a binary solvent system, $\mathrm{A}: \mathrm{B}$, which varied from 0 to $100 \% \mathrm{~B}$ ran at a flow rate of $1 \mathrm{~mL} \cdot \mathrm{min}^{-1}$ over 30 minutes where A consists of acetonitrile: $\mathrm{H}_{2} \mathrm{O}$, 5:95, $\mathrm{pH}$ adjusted to 4.0 with $\mathrm{H}_{3} \mathrm{PO}_{4}$ and $\mathrm{B}$ consists of acetonitrile: $\mathrm{H}_{2} \mathrm{O}, 90: 10$, $\mathrm{pH}$ adjusted to 4.0 with $\mathrm{H}_{3} \mathrm{PO}_{4}$. The mobile phase was returned to its original composition over the course of 30 minutes, and additional 10 minutes were allowed for the column to re-equilibrate before injection of the next sample. The sample volume was $10 \mu \mathrm{L}$ at a concentration of $1 \mathrm{mg} \cdot \mathrm{mL}^{-1}$ and the temperature was maintained at $25^{\circ} \mathrm{C}$ during the analysis. Detection was performed simultaneously at 210, 230, 254 and $280 \mathrm{~nm}$.
BIOLOGICAL ASSAYS

\section{Human Tumor Cells}

Three human tumor cell lines were used, Jurkat (human immortalized line of $\mathrm{T}$ lymphocyte), HL60 (human promyelocytic leukemia) and MCF-7 (breast cancer). HL60 and Jurkat cells were kindly furnished by Dr. Gustavo AmaranteMendes (Universidade de São Paulo, Brazil). MCF-7 was generously provided by Alfredo Goes (Universidade Federal de Minas Gerais, Brazil). All lineages were maintained in the logarithmic phase of growth in RPMI 1640 supplemented with 100 IU.mL $\mathrm{m}^{-1}$ penicillin and $100 \mu \mathrm{g} . \mathrm{mL}^{-1}$ streptomycin enriched with $2 \mathrm{mM}$ of L-glutamine and $10 \%$ of fetal bovine serum. All cultures were maintained at $37^{\circ} \mathrm{C}$ in a humidified incubator with $5 \% \mathrm{CO}_{2}$ and $95 \%$ air. The media were changed twice weekly and they were regularly examined. All cell lines were used between 16 and 30 passages.

\section{Parasites}

Four Leishmania species for in vitro screening were used: L. amazonensis (IFLA/Br/67/PH8), $L$. major (MRHO/SU/59/P), L. braziliensis (MHOM/ $\mathrm{Br} / 75 / \mathrm{M} 2903$ ) and L. chagasi (MHOM/Br/74/ PP75). Promastigotes of $L$. amazonensis and $L$. braziliensis were cultured in Warren's medium (brain heart infusion- BHI- plus hemin and folic acid), promastigotes of $L$. major were maintained in BHI medium, and promastigotes of $L$. chagasi were maintained in Medium 199, both supplemented with $10 \%$ fetal bovine serum at $24^{\circ} \mathrm{C}$.

\section{Antitumor and Antileishmanial Assays}

Cell viability was estimated by measuring the rate of mitochondrial reduction of tetrazoliumdye (MTT). MTT is a standard colorimetric assay, in which mitochondrial activity was measured by splitting tetrazolium salts with mitochondrial dehydrogenases in viable cells 
only (Mosmann 1983). To evaluate the antitumor activity, the tumor cell lines (Jurkat, HL60 and MCF-7) were inoculated at 50,000 cells per well. The plates were pre-incubated for $24 \mathrm{~h}$ at $37^{\circ} \mathrm{C}$ to allow cells adaptation prior to the addition of the test compounds. The half maximal inhibitory concentration $\left(\mathrm{IC}_{50}\right)$ was determined over a range of concentrations of a freshly prepared solution of (1) $(100.0 ; 50.0 ; 25.0 ; 12.5 ; 6.25 ; 3.12 ; 1.56 ; 0.78$; $0.39 \mu \mathrm{M})$ tested for $48 \mathrm{~h}$ in an atmosphere of $5 \%$ $\mathrm{CO}_{2}$ and $100 \%$ relative humidity. Control groups included treatment with $0.1 \%$ DMSO (negative control) and etoposide $14 \mu \mathrm{M}$ (positive control). All compounds were tested in triplicate, in three independent experiments (Monks et al. 1991). The antileishmanial activity was performed according to a previously described method (M'Bongo et al. 1997, Braga et al. 2007). Briefly, promastigotes from a logarithmic phase culture were suspended to yield 2 million cells. $\mathrm{mL}^{-1}$ (L. amazonensis) or 3 million cells. $\mathrm{mL}^{-1}$ (L. chagasi, L. braziliensis and L. major) after Neubauer chamber counting. The test was performed in 96-well microtiter plates maintained at $24^{\circ} \mathrm{C}$. The assays were performed in triplicate. The parasites were exposed to increasing concentrations of (1) $(100.0 ; 50.0 ; 25.0 ; 12.5 ; 6.25$; $3.12 ; 1.56 ; 0.78 ; 0.39 \mu \mathrm{M})$ for $72 \mathrm{~h}$ at $24^{\circ} \mathrm{C}$, for the determination of IC50 values. Controls with DMSO were also performed. Amphotericin B was used as the reference drug.

For both assays, after $4 \mathrm{~h}$ of the end of incubation of cells with different compounds, $20 \mu \mathrm{L}$ of MTT solution (5 mg.mL $\mathrm{m}^{-1}$ in phosphatebuffered saline) were added to each well, the supernatant was removed and $200 \mu \mathrm{L}$ of $0.04 \mathrm{M}$ $\mathrm{HCl}$ in isopropyl alcohol were added to dissolve the formazan crystal. The optical densities (ODs) were evaluated in a spectrophotometer at $590 \mathrm{~nm}$ (antitumor assay) and $570 \mathrm{~nm}$ (antileishmanial assay). Controls included drug-containing medium (background) and drug-free complete medium. Drug-free complete medium was used as control (blank) and was treated in the same way as the drug-containing media. Interactions between compounds and media were estimated on the basis of the variations between drug-containing medium and drug-free medium to avoid false-positive or false-negative results.

\section{DNA Fragmentation Assay}

Cell cycle status and quantification of DNA fragmentation (hypodiploid DNA-content) were performed by propidium iodide (PI) staining according to Nicoletti et al. (1991) Cells were treated with psychorubrin (1) $43 \mu \mathrm{M}$ in a $5 \% \mathrm{CO}_{2} / 95 \%$ air-humidified atmosphere at $37^{\circ} \mathrm{C}$ for $24 \mathrm{~h}$. After drug incubation, the cells were centrifuged and resuspended in hypotonic fluorochrome solution-HFS (50 $\mu$ g. $\mathrm{mL}^{-1}$ PI in $0.1 \%$ sodium citrate plus $0.1 \%$ Triton X-100). The samples in HFS were incubated at $4{ }^{\circ} \mathrm{C}$ during $4 \mathrm{~h}$ and immediately analyzed by flow cytometry. The PI fluorescence of 20,000 individual nuclei was measured using a FACScalibur flow cytometer (Becton Dickinson Immunocytometry Systems). The DNA content of cell lines was analyzed by FlowJo software (TreeStar Inc).

ANTIMICROBIAL ASSAY

\section{Microbial Strains}

The samples were evaluated against a panel of microorganisms, including the bacterial strains Staphylococcus aureus (ATCC 6538), Pseudomonas aeruginosa (ATCC 15442), Salmonella enterica sorovar typhimurium (ATCC 13311), Shigella sonnei (ATCC 11060), Klebsiella pneumoniae (ATCC 13866), Escherichia coli (ATCC 10536), Bacillus cereus (ATCC 11778), and the yeasts Candida albicans (ATCC 18804) and Cryptococcus neoformans (ATCC 32608). Bacterial strains were cultured overnight at $37^{\circ} \mathrm{C}$ in Mueller Hinton agar (MHA). Yeasts were cultured for $48 \mathrm{~h}$ at $30^{\circ} \mathrm{C}$ in Sabouraud dextrose agar (SDA). 
Serial Dilution Assay for Determination of the Minimal Inhibitory Concentration (MIC)

The minimal inhibitory concentration (MIC) of each extract was determined by using broth microdilution techniques as described previously for bacteria and yeasts, respectively (Perez et al. 1990, NCCLS 2002). MIC values were determined in RPMI 1640 buffered to a $\mathrm{pH} 7.0$ with MOPS for yeasts and Mueller Hinton broth (MHB) for bacteria. Yeasts were cultured at $30^{\circ} \mathrm{C}$ for $48 \mathrm{~h}$ in SDA and bacteria were cultured overnight at $37^{\circ} \mathrm{C}$ for $24 \mathrm{~h}$ in MHA. Stock solution of (1) was diluted two-fold from 2170 to $10.9 \mu \mathrm{M}$ (final volume $=80 \mu \mathrm{L}$ ) and a final DMSO concentration $\leq 1 \%$. Then, $100 \mu \mathrm{L}$ of RPMI or MHB were added onto microplates. Finally, $20 \mu \mathrm{L}$ of $10^{6}$ CFU.mL $\mathrm{mL}^{-1}$ (according to McFarland turbidity standards) of standardized yeasts and bacterial suspensions were inoculated onto microplates and the test was performed in a volume of $200 \mu \mathrm{L}$. Plates were incubated at $30^{\circ} \mathrm{C}$ for $48 \mathrm{~h}$ for yeasts and $37^{\circ} \mathrm{C}$ for $24 \mathrm{~h}$ for bacteria. The same tests were performed simultaneously for growth control (RPMI + yeast and MHB + bacteria) and sterility control (RPMI or MHB + psychorubrin). The MIC values were calculated as the highest dilution showing complete inhibition of tested strain. Chloramphenicol and amphotericin B were used as standard antimicrobial agents for bacteria and yeast, respectively.

\section{STATISTICAL ANALYSIS}

The $\mathrm{IC}_{50}$ values for antitumor and antileishmanial activities were determined using Prism 5.0 (GraphPad Software Inc.). Data were presented as median and 95\% confidence interval. Statistical differences between the treatments and the control were evaluated by ANOVA test. To express the DNA content, each data point represented mean \pm SD from at least two independent experiments performed in duplicate. Statistical differences between the treatments and the control were evaluated by ANOVA test followed by Bonferroni $(P>0.05)$.
Psychorubrin (3-hydroxy-3,4-dihydro-1Hbenzo[g]isochromene-5,10-dione, 1): amorphous off-white powder; $\mathrm{R}_{\mathrm{f}}=0.57$ (hexane:EtOAc 7:3), silica gel $60 \mathrm{~F}_{254}$; UV $\lambda_{\max } \mathrm{nm}(\mathrm{MeOH})$ 245, 250 (sh), 262, 333; IR (KBr) v 3409, 2925, 1666, $1297 \mathrm{~cm}^{-1} ;{ }^{1} \mathrm{H}$ NMR $\left(\mathrm{CDCl}_{3}, 300 \mathrm{MHz}\right)$

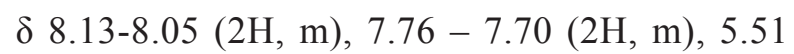
$(1 \mathrm{H}, \mathrm{t}), 4.81(1 \mathrm{H}, \mathrm{dt}), 4.71(1 \mathrm{H}, \mathrm{dt}), 2.84(1 \mathrm{H}$, dq), $2.74(1 \mathrm{H}, \mathrm{dq}) ;{ }^{13} \mathrm{C} \mathrm{NMR}\left(\mathrm{CDCl}_{3}, 75 \mathrm{MHz}\right)$ 183.7, 183.3, 141.5, 139.4, 134.1, 134.0, 132.2, 132.0, 126.7, 126.4, 90.9, 57.9, 28.2; EIMS, $\mathrm{m} / \mathrm{z}$ (relative intensity, \%) $230(5.1)[\mathrm{M}+], 212(17.1)$ $\left[\mathrm{M}^{+}-\mathrm{H}_{2} \mathrm{O}\right], 184$ (21.2) $\left[\mathrm{M}^{+}-\mathrm{HCO}_{2} \mathrm{H}\right], 173$ (4.9), 156 (9.2), 149 (16.3), 128 (7.0), 77 (15.8), 57 (46.5), 41 (100).

\section{RESULTS AND DISCUSSION}

Under the conditions used in the HPLC method, psychorubrin eluted as a narrow peak at 12.6 minutes and had a chromatographic purity of $98 \%$.

Our spectral data is in excellent agreement with that reported for both the natural and synthetic psychorubrin (1) (Hayashi et al. 1987, Kesteleyn et al. 1999, Bulbule et al. 2003, Nguyen and Kimpe 2004, Jacobs et al. 2008). Pyranonaphthoquinones are a diverse family of naturally occurring $1 H$-naphtho[2,3-c]pyran-5,10-diones, which are found in bacteria, fungi, aphids and higher plants (Thomson 1971).

Some of these presented antimicrobial, antiparasitic and anticancer properties (Lee et al. 1996, Wang et al. 1998, Krishnan and Bastow 2000). Psychorubrin (1) were also isolated from Psychotria rubra and $P$. camponutans that also belong to the Rubiaceae family (Hayashi et al. 1987). The fact that it was not reported outside this genus is an indication of its chemotaxonomical importance.

A literature search revealed few reports regarding to its biological activity although significant cytotoxicity against KB tumor cells has been previously reported (Hayashi et al. 1987). 
In our study, we demonstrated (Table I) that this compound is toxic against some tumor cells, including leukemia (HL60 and Jurkat), and solid tumors such as breast cancer (MCF-7). The antitumor activity observed in this study is supported by previous scientific reports on biological activities of other pyranonaphthoquinone derivatives as eleutherin, $\beta$-lapachone, and its structural isomer, $\alpha$-lapachone. The mechanism of topoisomerase II inhibition by those three derivatives was examined systematically with respect to the steps of the catalytic cycle of the enzyme. Etoposide, a topoisomerase inhibitor, was used as a control (Krishnan and Bastow 2000).

We investigated if the cytotoxic effects of psychorubrin (1) observed in our experiments were associated with its potential to induce cell death by apoptosis. We used the method described by Nicoletti et al. (1991) which is based on the principle that the apoptotic cells, among other typical features, are characterized by DNA fragmentation and, consequently, loss of nuclear DNA content. Apoptotic nuclei appeared as a broad hypodiploid DNA peak which was easily discriminable from the narrow peak of cells with normal (diploid) DNA content. This simple and reproducible method should prove useful for assessing apoptosis of specific cell populations in heterogeneous tissues. Our results (Figure 2) clearly demonstrated that psychorubrin induced an increase of subdiploid DNA content (DNA fragmentation) in HL60 and MCF-7 cell when compared with their respective control (DMSO 0.05\%). This effect was cell type dependent. To the resistant lineage MCF-7, psychorubrin (1) $(43 \mu \mathrm{M})$ demonstrated a proapoptotic potential better than etoposide $(14 \mu \mathrm{M})$, the clinical drug used as positive control in our experiments, possessing pro-apoptotic activities against several cancers.

In vitro cytotoxicity assays can be used to predict human toxicity and for the general screening of chemicals. Different cytotoxicity assays can give different results depending on the test agent used and the cytotoxicity assay employed (Fotakis and Timbrell 2006). In this context, the DNA content analysis revealed a different toxicity profile for psychorubrin compared with the MTT method. This effect can be attributed to the fact that MTT evaluates the energetic function of mitochondria that is preserved during the course of apoptosis. When the damage level to mitochondria is mild or moderate, mitochondria can still generate sufficient energy for initiation and execution of the apoptotic process

TABLE I

Antitumor and antileishmanial activity of psychorubrin (1).

\begin{tabular}{|c|c|c|c|c|c|c|c|}
\hline \multirow{3}{*}{ Samples } & \multicolumn{3}{|c|}{ Antitumor activity $^{\mathrm{a}}$} & \multicolumn{4}{|c|}{ Antileishmanial activity $^{\mathrm{a}}$} \\
\hline & \multicolumn{3}{|c|}{$\mathrm{IC}_{50}(\mu \mathrm{M})$} & \multicolumn{4}{|c|}{$\mathrm{IC}_{50}(\mu \mathrm{M})$} \\
\hline & HL60 & Jurkat & MCF-7 & $\mathrm{La}$ & $\mathrm{Lc}$ & $\mathrm{Lb}$ & $\mathrm{Lm}$ \\
\hline \multirow[t]{2}{*}{ Psychorubrin } & 4.5 & 5.6 & 1.1 & 2.7 & 1.7 & 1.7 & 2.4 \\
\hline & $(4.1-5.0)$ & $(5.1-6.1)$ & $(0.4-2.6)$ & $(2.0-3.0)$ & $(1.0-2.2)$ & $(0.9-2.1)$ & $(1.6-3.1)$ \\
\hline \multirow[t]{2}{*}{ Amphotericin $\mathrm{B}^{\mathrm{b}}$} & - & - & - & 0.9 & 1.9 & 0.1 & 0.3 \\
\hline & & & & $(0.2-1.7)$ & $(1.7-2.4)$ & $(0.05-0.2)$ & $(0.1-0.5)$ \\
\hline \multirow[t]{2}{*}{ Etoposide $^{\mathrm{c}}$} & 0.5 & 2.5 & $>50$ & - & - & - & - \\
\hline & $(0.3-0.9)$ & $(0.9-7.3)$ & & & & & \\
\hline
\end{tabular}

${ }^{\mathrm{a}}$ La - Leishmania amazonensis; Lc-Leishmania chagasi; Lb - Leishmania braziliensis; Lm - Leishmania major. Data are presented as median and 95\% confidence interval (in parentheses).

b,c Positive controls. 


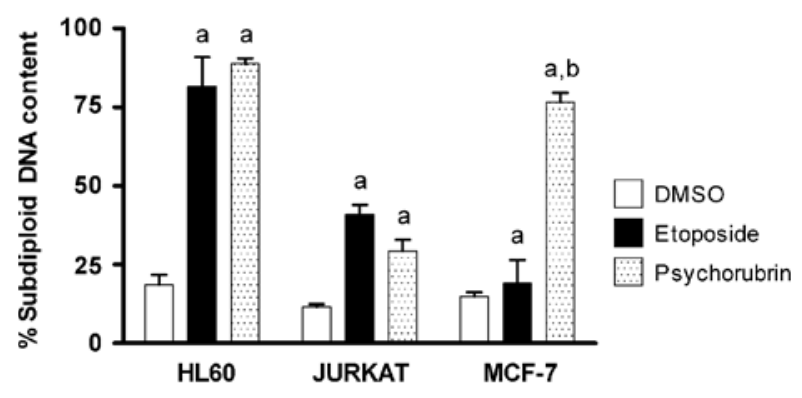

Figure 2 - Effect of psychorubrin (1) on DNA content of tumor cell lines. HL-60, Jurkat e MCF-7 cells were incubated with $43 \mu \mathrm{M}$ psychorubrin or with $0.05 \%$ DMSO for $24 \mathrm{~h}$. DNA content was assayed by PI stain and flow cytometry analysis. Etoposide $(14 \mu \mathrm{M})$, positive control is demonstrated. Each data point represents mean \pm SD from at least two independent experiments performed in duplicate. ${ }^{a}$ Statistically different from negative control (DMSO). ${ }^{\mathrm{b}}$ Statistically different from positive control (etoposide) (ANOVA followed by Bonferroni, $P>0.05$ ).

(Yang et al. 2010). The increase of subdiploid DNA content (DNA fragmentation) observed in HL60 and MCF-7 cells after psychorubrin treatment suggested that this compound activates the apoptosis pathway. Many chemotherapeutic strategies interfere with important steps in cell cycle progression such as DNA replication and repair. They act as DNA polymerase inhibitors, topoisomerase inhibitors, or DNA alkylating agents to impede cancer progression and induction of apoptosis as a secondary effect (Li et al. 2006). Apoptosis is accompanied by the shrinkage and fragmentation of both cells and their nuclei, loss of microvilli, and extensive degradation of chromosomal DNA. Degradation of nuclear DNA into nucleosomal units is one of the hallmarks of apoptotic cell death. Molecular characterization of this process demonstrated that the chromosomal DNA cleavage is caspase-dependent, in particular caspase 3 cleaves ICAD to dissociate the CAD:ICAD complex, allowing CAD to cleave chromosomal DNA (Nagata 2000). Despite the cell mechanism involved on DNA fragmentation induced by psychorubrin in HL60 and MCF-7 cells were not described in the present work, our results suggest that this compound has a potential antitumoral activity, inducing the apoptotic pathway.
Psychorubrin (1) also presented an interesting antileishmanial activity with $\mathrm{IC}_{50}$ values above $3 \mu \mathrm{M}$ against promastigote forms of different Leishmania species (Table I). Leishmaniasis is a debilitating disease caused by protozoan parasites of the genus Leishmania, which affects an estimated 12 million people worldwide. The discovery of new lead compounds for leishmaniasis is therefore a pressing concern for global health programs (Sanchez et al. 2010).

We also demonstrated that psychorubrin (1) displayed a broader spectrum of antimicrobial activity, most particularly against $C$. neoformans (MIC of $10 \mu \mathrm{M}$ ), (Table II), an opportunistic yeast and etiological agent of cryptococcosis. Cryptococcosis is an opportunistic systemic mycosis that involves the central nervous system, especially in immunocompromised patients (Perfect and Casadevall 2002). Cryptococcosis is currently treated with amphotericin B/azoles as the main therapeutic choice (Van der Horst et al. 1997). Nevertheless, the high lethality rate among immunocompromised patients indicates that new therapeutic options are necessary.

TABLE II

Antimicrobial activity of psychorubrin (1).

\begin{tabular}{lcc}
\hline Test microorganisms & $\mathrm{MIC}^{\mathrm{a}}$ & $\mathrm{S}^{\mathrm{b}}$ \\
\hline Bacteria & & \\
Staphylococcus aureus & 340.3 & $193.4^{\mathrm{c}}$ \\
Escherichia coli & 340.3 & $48.3^{\mathrm{c}}$ \\
Salmonella typhimurium & 340.3 & $3.1^{\mathrm{c}}$ \\
Shigella sonnei & 340.3 & $3.1^{\mathrm{c}}$ \\
Klebsiella pneumoniae & 680.6 & $3.1^{\mathrm{c}}$ \\
Bacillus cereus & 170.2 & $12.1^{\mathrm{c}}$ \\
Pseudomonas aeruginosa & 680.6 & $48.3^{\mathrm{c}}$ \\
Yeasts & & \\
Candida albicans & 340.3 & $0.09^{\mathrm{d}}$ \\
Cryptococcus neoformans & 87.3 & $0.05^{\mathrm{d}}$ \\
\hline \multicolumn{2}{c}{${ }^{\mathrm{a}}$ Minimal inhibitory concentration $(\mu \mathrm{M})}$. \\
${ }^{\mathrm{b}}$ Standard antimicrobial agents $(\mu \mathrm{M}){ }^{\mathrm{c}}$ Chloramphenicol; ${ }^{\mathrm{d}}$ Amphotericin B.
\end{tabular}


In conclusion, the results obtained in this work reinforce that pyranonapthoquinones are an important class of natural products for investigation in the search of new bioactive compounds. In this regard, psychorubrin (1) displayed a very promising antitumor and antimicrobial activity, mainly against $C$. neoformans. A pronounced antileishmanial potential was also observed. Furthermore, this is the first report of the presence of pyranonapthoquinones in the Mitracarpus genus, which may serve as a chemotaxonomical marker.

\section{ACKNOWLEDGMENTS}

The authors are grateful to Fundação de Amparo à Pesquisa do Estado de Minas Gerais (FAPEMIG - CEX APQ 2874-5.02/07, CEX APQ 01137/09, CBB PPM00149-10 and CBB APQ-02740-09) and Universidade Federal de Juiz de Fora (UFJF)/ Brazil for financial support, to Dra. Tatiana Konno for the botanical identification of species and to Delfino Antonio Campos for technical assistance.

\section{RESUMO}

O fracionamento biomonitorado do extrato diclorometânico de Mitracarpus frigidus forneceu a piranonaftoquinona psicorubrina. Essa substância, até então desconhecida no gênero Mitracarpus, teve sua atividade biológica avaliada contra várias bactérias e dois fungos, três linhagens de células tumorais (HL60, Jurkat e MCF-7) e quatro espécies de Leishmania. Sua estrutura foi confirmada por meio de ${ }^{1} \mathrm{H},{ }^{13} \mathrm{C},{ }^{1} \mathrm{H}-\mathrm{COSY}$, IR e UVVis e espectrometria de massas. Psicorubrina exibiu uma atividade antitumoral promissora com CI50 de 4,5, 5,6 e 1,1 $\mathrm{MM}$ para HL60, Jurkat e MCF-7, respectivamente. Atividade antimicrobiana, principalmente contra Cryptococcus neoformans (CIM de 87,3 $\mu \mathrm{M}$ ), foi observada. Um pronunciado potencial leishmanicida também foi verificado com $\mathrm{CI}_{50}$ variando de $1,7-2,7 \mu \mathrm{M}$ para as diferentes espécies de Leishmania testadas. Este é o primeiro relato da presença de piranonaftoquinonas no gênero Mitracarpus, que poderão ser úteis como marcadores quimiotaxonômicos.
Palavras-chave: Mitracarpus frigidus, psicorubrina, piranonaftoquinona, Rubiaceae.

\section{REFERENCES}

ARrUDA RCO AND GOMES DMS. 1996. Anatomia foliar de Mitracarpus frigidus (Wild.) K. Schum. var. salzmannianus (DC) K. Schum. e Mitracarpus lhorzkianus Cham (Rubiaceae), São Paulo: Herbarium Bradeanum, 14 p.

Bisignano G, SANogo R, Marino A, Aquino R, D'Angelo V, Germano MP, de Pasquale R and Pizza C. 2000. Antimicrobial activity of Mitracarpus scaber extract and isolated constituents. Lett Applied Microbiol 30: 105-108.

BRAGA FG, BOUZADA MLM, FABRi RL, MATOS MO, MOREIRA FO, SCIO E AND COIMBRA ES. 2007. Antileishmanial and antifungal activity of plants used in traditional medicine in Brazil. J Ethnopharmacol 111: 396-402.

Bulbule VJ, Koranne PS, Munot YS, Borate HB And DESHPANDE VH. 2003. Simple synthesis of two naphthoquinone antibiotics psychorubrin and pentalongin. Synthetic Commun 33: 587-594.

EKPENDU TOE, AdESOMOJU AA AND OKOGUN JI. 2001. Chemical studies of Mitracarpus villosus (Sw.) DC - a medicinal rubiaceous weed. J Chem Soc Nigeria 26: 69-74.

FABri RL, Nogueira MS, Braga FG, COIMBra ES AND SCIO E. 2009. Mitracarpus frigidus aerial parts exhibited potent antimicrobial, antileishmanial, and antioxidant effects. Bioresource Technol 100: 428-433.

FotAKIS G AND TIMBRELL JA. 2006. In vitro cytotoxicity assays: Comparison of LDH, neutral red, MTT and protein assay in hepatoma cell lines following exposure to cadmium chloride. Toxicol Lett 160: 171-177.

Gbaguidi F, ACCROMBessi G, MOUdACHIROU M AND QUETIN-LECLERCQ J. 2005. HPLC quantification of two isomeric triterpenic acids isolated from Mitracarpus scaber and antimicrobial activity on Dermatophilus congolensis. J Pharm Biomed Anal 39: 990-995.

GREFF D. 1998. Cosmetic and pharmaceutical compositions for beautifying and lightening skin containing Mitracarpus extracts. PCT Int Appl WO 9805299.

Harouna H, Faure R, Elias R, Debrauwerm L, SaAdou M, BALANSARD G AND BOUdON G. 1995. Harounoside a pentalongin hydroquinone diglycoside from Mitracarpus scaber. Phytochemistry 39: 1483-1484.

HAYASHI T, SMITH FT AND LEE KH. 1987. Antitumor agents. 89. Psychorubrin, a new cytotoxic naphthoquinone from Psychotria rubra and its structure-activity relationships. J Med Chem 30: 2005-2008.

Jacobs J, Claessens S AND DE KIMPE N. 2008. First straightforward synthesis of 1-hydroxy-3,4-dihydro-1Hbenz $[\mathrm{g}]$ isochromene-5,10-dione and structure revision of a bioactive benz[g]isochromene-5,10-dione from Psychotria camponutans. Tetrahedron 64: 412-418.

Kesteleyn B, DE KIMPE N AND VAN Puyvelde L. 1999. Synthesis of two naphthoquinone antibiotics pentalongin and psychorubrin. Synthesis 11: 1881-1883. 
KRISHNAN P AND BASTOW KF. 2000. Novel mechanisms of DNA topoisomerase II inhibition by pyranonaphthoquinone derivatives eleutherin, $\alpha$-lapachone, and $\beta$-lapachone. Biochem Pharmacol 60: 1367-1379.

LEE H, Hong SS AND KIM YH. 1996. Synthesis and in vitro evaluation of 3-substituted-1-azaanthraquinones. Bioorg Med Chem Lett 6: 933-936.

Li W, LAM MS, Birkeland A, Riffel A, Montana L, Sullivam ME AND Post JM. 2006. Cell-based assays for profiling acticity and safety properties of cancer drugs. J Pharmacol Toxicol Methods 54: 313-319.

M'Bongo N, Loiseau P, LaWrence F, Bories C, Craciunescu DG AND ROBERT-Gero M. 1997. In vitro sensivity of Leishmania donovani to organometallic derivatives of pentamidine. Parasitol Res 83: 515-517.

Monks A, Scudiero D, Skehan P, Shoemaker R, PAull K, Vistica D, Hose C, LANGley J, Cronise P AND VAigroWOLFF A. 1991. Feasibility of a high-flux anticancer drug screen using a diverse panel of cultured human tumor cell lines. J Natl Cancer I 83: 757-766.

MosmanN T. 1983. Rapid colorimetric assay for cellular growth and survival: application to proliferation and cytotoxicity assays. Immunol Methods 65: 55-63.

Moulis C, Pelisier J, Bamba D AND Fourasté L. 1992. Pentalongin, antifungal naphthoquinoid pigment from Mitracarpus scaber. Proceeding of the $2^{\text {nd }}$ International Congress on Ethnopharmacology, July 2-4, 1992, Uppsala, Sweden.

NAGATA S. 2000. Apoptotic DNA fragmentation. Exp Cell Res 256: $12-18$.

NCCLS - NATIONAL COMMITTEE FOR CLINICAL LABORATORY STANDARDS. 2002. Reference method for broth dilution antifungal susceptibility testing of yeasts. Approved standard M27-A2 - P. National Committee for Clinical Laboratory Standards. Wayne, PA.

NGUYEN VT AND DE KIMPE N. 2004. Synthesis of pyranonaphthoquinone antibiotics involving the ring-closing metathesis of vinyl ether. Tetrahedron Lett 45: 3443-3446.
Nicoletti I, Miglioratim G, PAgLiaccim MC, GRignanim F AND RICCARDI C. 1991. A rapid and simple method for measuring thymocyte apoptosis by propidium iodide staining and flow cytometry. J Immunol Methods 139: 271-279.

OKunADE AL, Clark AM, HufFord CD AND OGUNTIMEIN BO. 1999. Azaanthraquinone: an antimicrobial alkaloid from Mitracarpus scaber. Planta Med 65: 447-448.

Perez C, Pauli M And Bazerquem P. 1990. An antibiotic assay by the well agar method. Acta Biol Med Exp 15: 113-115.

Perfect JR AND CASAdeVAll A. 2002. Cryptococcosis. Infect Dis Clin North Am 16: 837-874.

SANChez LM, Lopez D, VeSEly BA, TOGNA GD, Gerwick WH, KYlE DE AND Linington RG. 2010. Almiramides A-C: Discovery and Development of a New Class of Leishmaniasis Lead Compounds. J Med Chem 53: 4187-4197.

SPINDLER R AND URBANEC SJ. 2009. Improved skin brightening compositions. PCT Int. Appl. WO 2009/099911.

THOMSON RH. 1971. Naturally Occuring Quinones. $2^{\text {nd }}$ ed., London: Academic, $282 \mathrm{p}$.

TSUJI D AND NAKANISHI H. 2010. Skin-conditioning compositions containing fucoxanthin and hydroquinone derivative and cosmetics, skin-lightening compositions, and cosmetic creams containing them. JP 2010/209023.

VAN DER HoRST CM ET AL. 1997. Treatment of Cryptococcal Meningitis Associated with the Acquired Immunodeficiency Syndrome. N Engl J Med 337: 15-21.

Wang W, Li T, Milburn R, Yates J, Hinnant E, Luzzio MJ, Noble SA AND ATtARdo G. 1998. Novel 1,3-disubstituted-5,10-dihydro-5,10-dioxo- $1 H$-mbenzo[ $g]$ isochromene-3-carboxamides as potent antitumor agents. Bioorg Med Chem Lett 8: 1579-1584.

YANG W, Hu B, Sun J, Zhai S AND Donald H. 2010. Death mode-dependent reduction in succinate dehydrogenase activity in hair cells of aging rat cochleae. Chin Med J 123: $1633-1638$. 